\title{
Managing Effectiveness of Public Health Performance in Surabaya City
}

Andy Fefta Wijaya ${ }^{1}$

Priyo Budi Santoso ${ }^{2}$

Agus Suryono ${ }^{3}$

Tjahjanulin Domai ${ }^{4}$

Faculty of Administrative Science, Universitas Brawijaya - Indonesia

\begin{abstract}
This paper studies about managing the effectiveness of public health performance in Surabaya City, Indonesia. The research method uses a qualitative approach through focus group discussion elaborated with secondary data of the health sector performance. This paper proves that vertical and horizontal balanced performance measurements in the health sector are essential. Vertical stable performance is in the context of a hierarchical performance of top-level performance and lower-level performance in the public institution. In contrast, a horizontal balanced performance is the arrangement of qualitative and quantitative performance indicators and targets.
\end{abstract}

Keywords: Public Management, Performance Management, Public Health Performance

\footnotetext{
${ }^{1}$ Andy Fefta Wijaya is a lecturer at Faculty of Administrative Science, Universitas Brawijaya. Email: andyfeftawijaya@gmail.com

${ }^{2}$ Priyo Budi Santoso is a doctoral student at Faculty of Administrative Science, Universitas Brawijaya.

${ }^{3}$ Agus Suryono is a lecturer at Faculty of Administrative Science, Universitas Brawijaya.

${ }^{4}$ Tjahjanulin Domai is a lecturer at Faculty of Administrative Science, Universitas Brawijaya.
} 


\section{Managing Effectiveness of Public Health Performance in Surabaya City}

Andy Fefta Wijaya, Priyo Budi Santoso, Agus Suryono, and Tjahjanulin Domai

\section{Introduction}

Result-oriented management is the current approach in many public sectors, including public health sector performance. The public organizational management must put result/ outcome and impact performance in the first priority in the "New Public Management' paradigm. In the public strategic management is placed in the level of goals that are expected to drive their performance for vision and mission achievements. Osborne \& Plastrik, 2000, p. 252 states that policy goals and missions are considered as a representation of 'desired policy outcome.' The other scholars say as a 'desired outcome' (Osborne \& Gaebler, 1992, p. 35 1; SCRGSP, 2004, p. 1.12). Managing the desired outcome is related to achieve the organization's goal effectiveness by arranging among organizational input, process, output, and outcome/impact aspect. Performance indicators are used to inform the decisionmaker, such as the City Mayor, on how the development progress is going on. One of the goal performance indicators is the Human Development Index (HDI).

Human Development Index (HDI) is an essential component of life quality composing three aspects. The first aspect is life expectancy, that represents the health dimension. The second aspect is the expected years of schooling (EYS) and means years of schooling (MYS) that represents the educational dimension. The last element is purchasing power parity that serves a decent living aspect. HDI in Surabaya City from 2015 to 2017 tends to increase, as shown in Diagram 1 below from 79,47 in 2015 to 80,38 in 2016 and 81,07 in 2017. This figure is categorized in the highest level group of HDI achievement in Indonesia (HDI $\geq 80$ ).

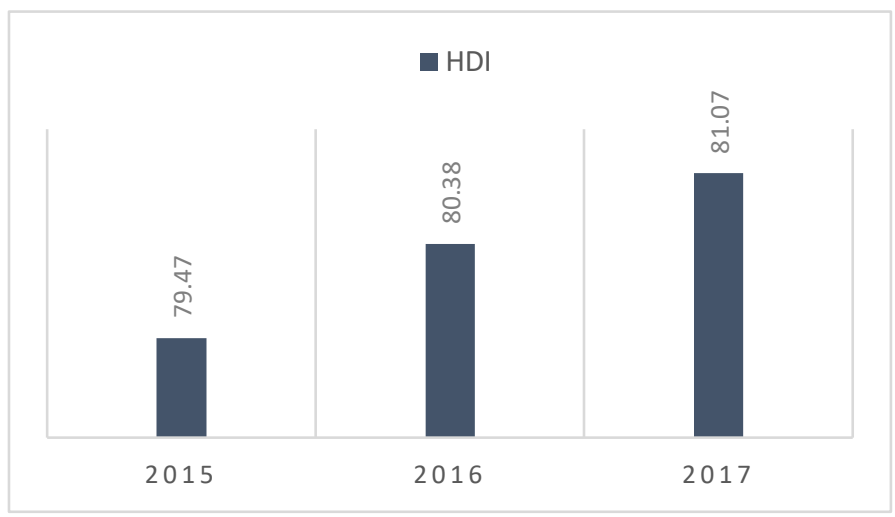

Diagram 1. HDI in the Surabaya City 2015-2017

Source: the Surabaya Local Statistic Bureau, 2018

The HDI improvement of Surabaya City is pushed by the escalation of education and purchasing index. The education index increased from 0,72 in 2015 to 0,74 in 2016 and 0,75 in 2017 . The purchasing index raised from 0,84 in 2015 to 0,85 in 2016 and 0,86 in 2017. However, the health index is stable in 0,83 from 20152017, as shown in Diagram 2 below. This paper wants to analyze public health performance in the Surabaya City and improvement aspects of this sector. 


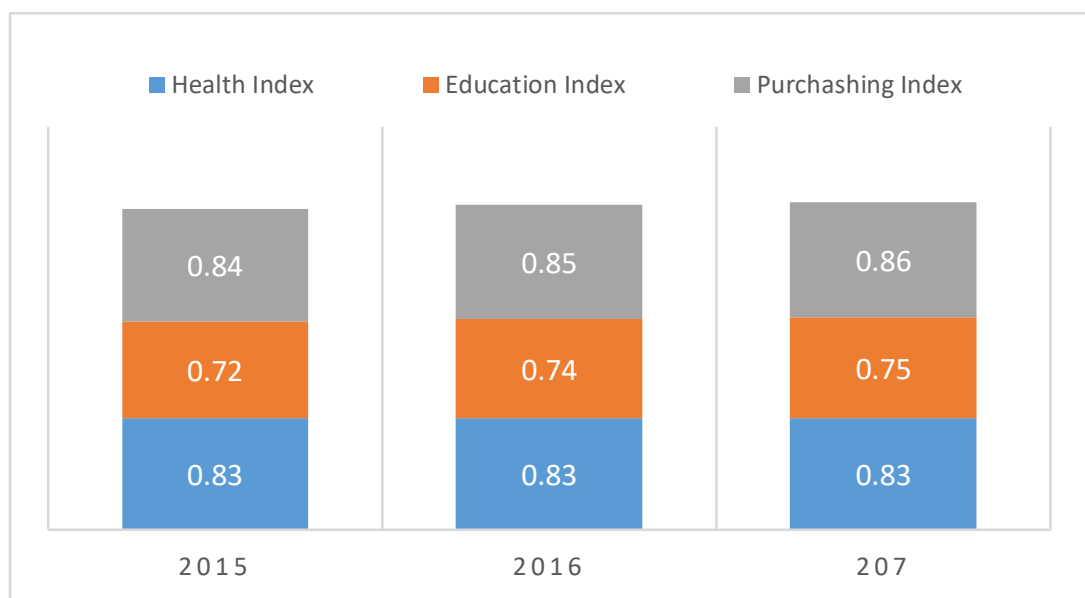

Diagram 2. Index Components of HDI in the Surabaya City 2015-2017

Source: the Surabaya Local Statistic Bureau, 2018

In managing the public health sector, different responses may be given by the field implementers. Performance targets have been set up, but the performance achievements do not improve. It can be caused by the fact that vertically and horizontally, performance targets do not match each other. As mentioned by Pressman \& Wildavsky, 1984, p. 171 that setting an optimal effort into policy goal achievement is excellent, but it should be understood that policy goals have performance constraints.

\section{Theoretical Discussion}

Multiple goals of public sectors covering and balancing aspects of economic, social, and environmental are quite commons (Turner and Hulme, 1997, p 182). All elements need to well and fit measured, otherwise like Turner and Hulme mention, a performance accountability system is 5becoming weak and an absence of suitable performance assessment criteria (Turner \& Hulme, 1997, p. 182). In the unclear measurement of goals and targets, elites can manipulate the situation to act on behalf of solely public missions, but taking personal benefits from their action. So, accountability to citizens is obscure, and it can only be secured through open, transparent, accountable, and effective mechanisms (Murphy, 1998, pp. 23-4). Effective implementation is achieved by integrating public policy and management together (Sandfort and Moulton, 2015).

Managing performance measures requires qualitative learnings from participants (Midgley, 2000, p. 233). Various service users within the many need to take into account in the measurement process. Multidimensional performance measures are taking on the values of many stakeholders with diverse backgrounds. McIntyre-Mills states that "service needs to reflect the values of the users and for this to occur the users need to participate in and decide on policy design and 
governance" (McIntyre-Mills, 2003, p. 14). Performance measurement systems are operated to fill in a gap between service providers and users. Managing the effectiveness of goal achievements and services are put in the context of numerous users' opinions. So, governance is urgent to manage well the public institution.

Kooiman (2003, p. 139) defined governance as "arrangements in which public as well as private actors aim at solving societal problems or create societal opportunities, and aim at the care for the societal institutions within which these governing activities take place." Governance is correlated with the concepts of 8 'interorganizational networks' (Rhodes, 2003, p. 15), 'links' (Kettl, 2002, p. 119), 'interactions' (Kooiman, 2003, p. 4; Work, 2003, p. 195) and 'relations' (Frederickson \& Smith, 2003, p. 222) among institutions and individuals in the three interconnected areas: public, private, and society sectors. As Kooiman (2003, p. 1178) said, "in modern (public) governance top-down control is still an important mode of controlling complex activities, but other arrangements providing checks and balances, and even bottom-up control, are widespread to cope with complexity." Managing performance is essential in a governing complexity involving government, community, and business sectors. In this process, capacity building is needed. As mentioned by Fukuyama (2004, p. 119-21) is that state capacity building is important, and it is not in terms of massive and all-powerful governments to control all aspects of social and economic life. As Rondinelli and Cheema assert, a competent government is essential than a powerful government. A relevant government in a complex and changing global society concerns democratic and governance values that can lead the community toward the world sustainability in the environment, social and economic sectors (Rondinelli \& Cheema, 2003, p. 243).

\section{Research Method}

This research paper uses a qualitative approach. The research location is in Surabaya City. Data Collection uses secondary data from public documents. Focus group discussions are used to get qualitative data in the field. Content analysis is employed to get information from the government reports genuinely.

\section{Analysis of Health Performance in Surabaya City}

Findings in this research approve that the full coverage service of the target group is not automatically linear with the satisfaction of the service given. It means that the quantity performance target is no guarantee for the target group people who will satisfy with the service quality level. In Surabaya City, the health service coverage for the poor is achieved by $100 \%$ as the first target. It can be seen in Graphic 1 below.

However, the performance achievement of the health service coverage above is not equivalent to the health service satisfaction index for the poor inhabitant. In 2016, the health satisfaction index was 76, but in 2017 it decreased to 68,73. In terms of target, achievement fails. The objective was 70 in 2016, but the realization is 68,73 . So the target achievement is $98,19 \%$ as shown in Graphic 2 below 


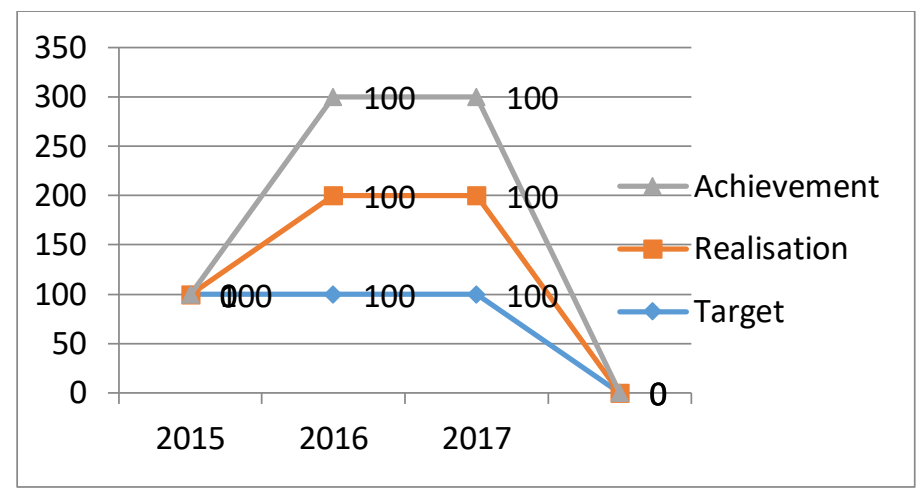

Graphic 1. The Service Coverage for the poor in the Surabaya Public Health

Service in 2015-2017 in Percentages

Source: the Surabaya Local Statistic Bureau, 2018

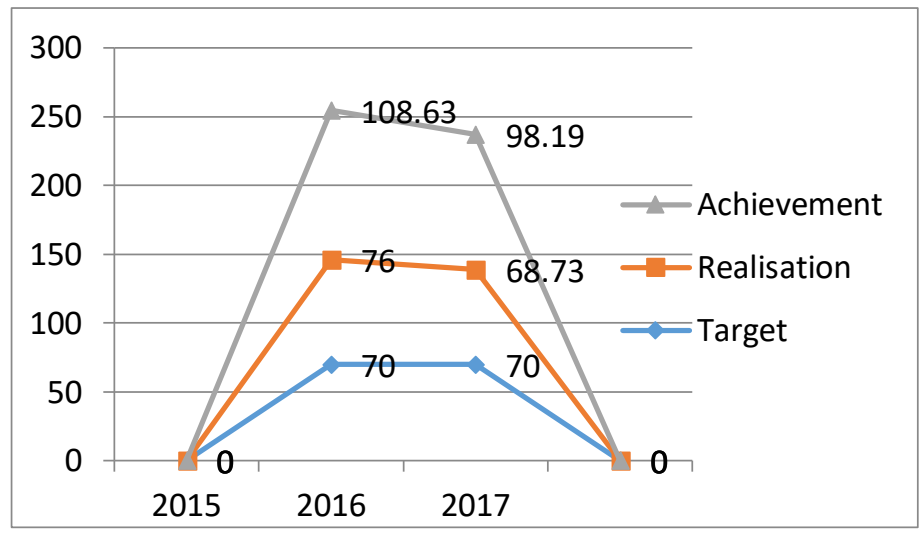

Graphic 2. Index of Health Service Satisfaction for the Poor Inhabitant in

Surabaya in 2015-2017

Source: the Surabaya Local Statistic Bureau, 2018

Moreover, the facts below approve that even though service performance targets are achieved, but the number of target groups who are dying still exists. It means that the measurement of service quality performance must be balanced with the quantitative analysis. Service coverage for 'Nifas' mother (post-natal bleeding) on Graphic 3 achieves $100 \%$ from target to realization. However, it is only 94,53\% of target realization. It means that $5,47 \%$ of the target group is not covered. 


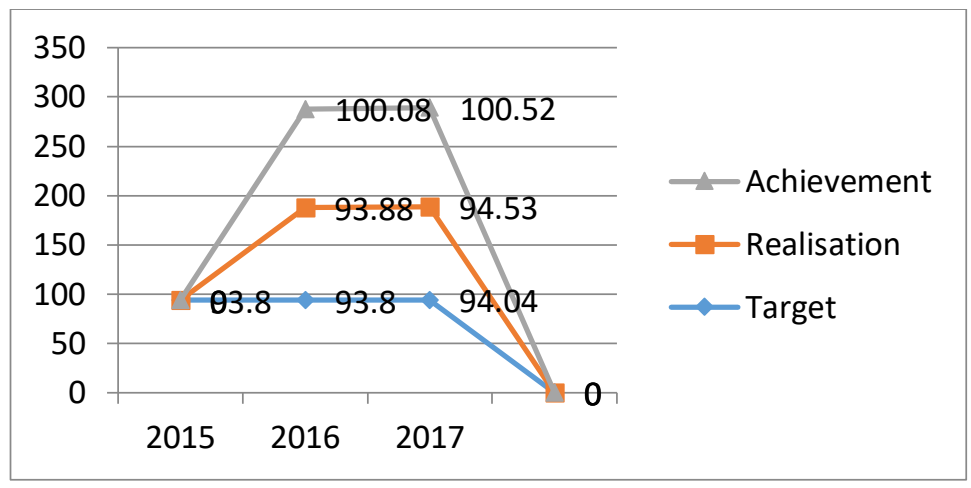

Graphic 3. Service Coverage for Nifas Mother (Post-Natal Bleeding) Source: the Surabaya Local Statistic Bureau, 2018

The maternal mortality rate per 100.000 in Live Birth achieves $100 \%$ of the target from 84,07 target to 79,4 realization, but the number of mothers dies per 100.000 in live birth that is 79 women, as shown in Graphic 4.

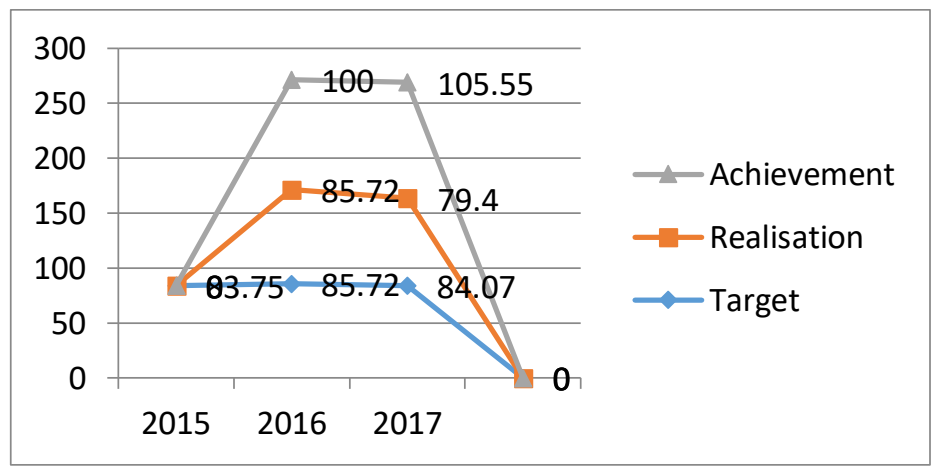

Graphic 4. Maternal Mortality Rate per 100.000 in Live Birth Source: the Surabaya Local Statistic Bureau, 2018

The same situation in the baby's health service covers $95,97 \%$ of the target population. It also means $101,93 \%$ target achievement. But, it still leaves homework about $4 \%$ of babies who are not served by the government. It is showed in the Graphic 5 below.

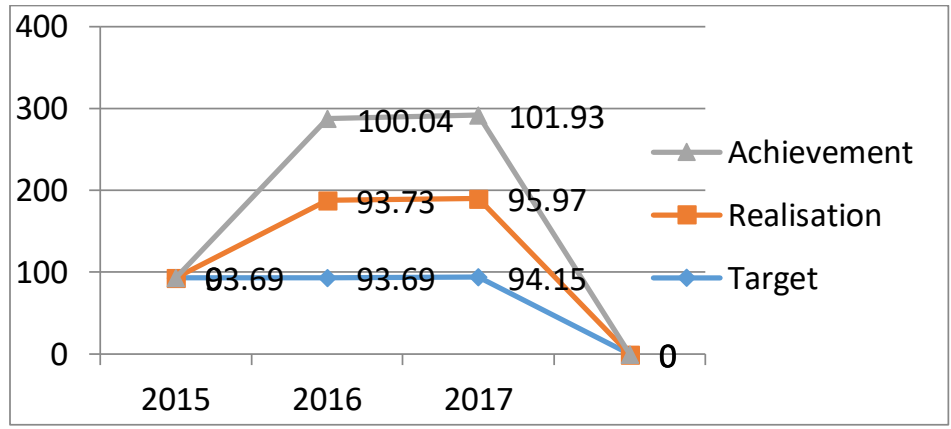

Graphic 5. Baby's Health Service Coverage

Source: the Surabaya Local Statistic Bureau, 2018 
As a consequence, the infant mortality rate is 6,39 in 2016 and then decrease to 5,11 in 2017 per 100 live birth, as shown in Graphic 5. Even though the date infant rate achieves the target every year, but this aspect needs to be handled seriously until the infant mortality rate is in a low score.

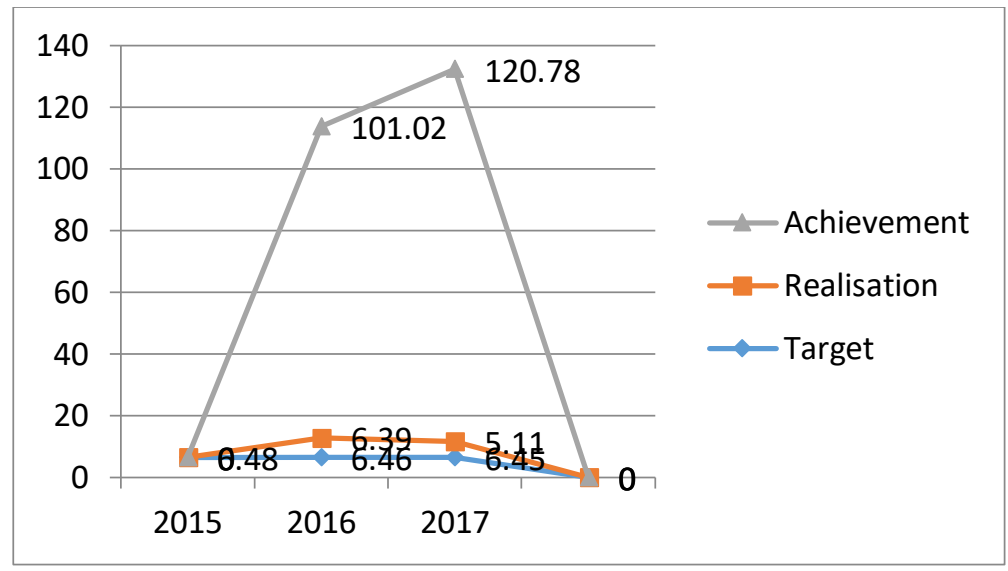

Graphic 6. Infant Mortality Rate per 1.000 Live Birth Source: the Surabaya Local Statistic Bureau, 2018

Furthermore, the number of unaccredited community health centers is still available, as shown in Graphic 7 below. It is about $11 \%$ of the community health center not accredited yet. Achievement of accreditation is an indicator of how it is good that the community health center operates. It means that organizational performance standard is the target that needs to be full filled.

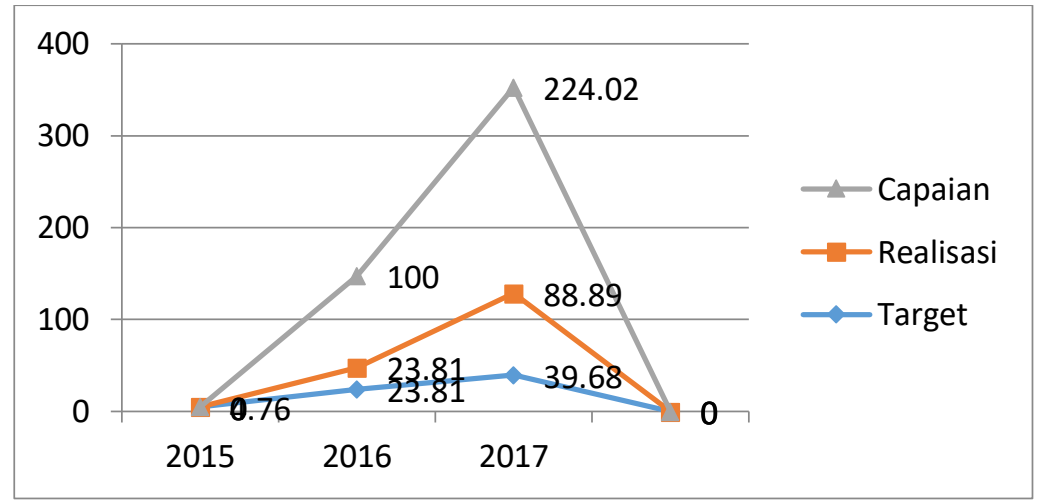

Graphic 7. Accredited Community Health Center in 2015-2017

Source: the Surabaya Local Statistic Bureau, 2018

From the three findings above, it is found that hindrances that come up to the public health sector are including hospitals that work with the social and healthcare security administration body (BPJS) are still 37 from the 59 hospitals in Surabaya. It means that several hospitals relatively choose to work independently and do not joint with the BPJS in the health sector. Then, people expect health service performance improvement also increases. It insists on the public health sector to work harder. The other point is about incomplete data of the poor by name 
by address. Several poor people can sometimes move from the low income at the poor level group to the higher income status, but their data are still not changed. So they always get the benefit.

\section{Conclusion \& Recommendation}

It can be concluded from the case of public health sector performance that qualitative performance measurement needs to be balanced horizontally with quantitative performance measurement and vice versa. The other conclusion is that the achievements of accredited performance standards are urgent to improve the outcome achievement of health sector performance. A balanced vertical performance arrangement in hierarchical performance is needed to match between upper and lower performance achievements. Moreover, several aspects of the health sector in Surabaya City have to improve, firstly, health service satisfaction from the poor target group. The second is improvements in health services such as service coverage for Nifas Mother (Post-Natal Bleeding) and baby's health service. The last is to push down the number of infant and mortality death.

\section{References}

BPS (2018). Surabaya in Number (Surabaya dalam Angka), Surabaya Statistics Center Bureau.

Frederickson, H. G., \& Smith, K. B. (2003). Public Administration Theory Primer. Colorado: Westview Press.

Fukuyama, F. (2004). State-Building: Governance and World Order in the 21st Century. Ithaca: Cornell University Press.

Kettl, D. F. (2002). The Transformation of Governance. Baltimore: The Johns Hopkins University Press.

Kooiman, J. (2003). Governing as Governance. London: Sage Publications.

McIntyre-Mills, J. (2003). Critical Systemic Praxis for Social and Environmental Justice. New York: Kluwer Academic.

Midgley, G. (2000). Systemic Intervention: Philosophy, Methodology, and Practice. New York: Kluwer Academic.

Murphy, K. (1998). Accountability to the Citizens. In R. Boyle \& T. McNamara (Eds.), Governance and Accountability (pp. 23-39). Dublin: Institute of Public Administration.

Osborne, D., \& Gaebler, T. (1992). Reinventing Government How the Entrepreneurial Spirit Is Transforming the Public Sector. New York: The Penguin Books.

Osborne, D., \& Plastrik, P. (2000). The Reinventor's Fieldbook. San Fransisco: Jossey-Bass.

Pressman, J. L., \& Wildavsky, A. (1984). Implementation (3rd ed.). Berkeley: University of California Press.

Rondinelli, D. A., \& Cheema, G. S. (2003). The Competent State: Governance and Administration in an Era of Globalization. In D. A. Rondinelli (Ed.), Reinventing Government for the Twenty-First Century: State Capacity in a Globalizing Society (pp. 243-260). Bloomfield: Kumarian Press.

Sandfort, Jodi, and Moultan, S., (2015). Effective Implementation in Practice, JosseyBass, San Fransisco

SCRGSP. (2004). Report on Government Services 2004. Retrieved 14 April, 2005, from http://www.pc.gov.au/gsp/reports/rogs/2004/index.html 
Andy Fefta Wijaya, Priyo Budi Santoso, Agus Suryono, and Tjahjanulin Domai

Turner, M., \& Hulme, D. (1997). Governance, Administration and Development: Making the State Work. Houndmills: Macmillan Press.

Weiss, C. H. (1998). Evaluation (2nd ed.). New Jersey: Prentice Hall.

WHO. (1994). Financial Management of Water Supply and Sanitation: a Handbook. Geneva: World Health Organization (WHO).

Wholey, J. S., \& Hatry, H. P. (1992). The Case for Performance Monitoring. Public Administration Review, 52(6), 604-610.

Work, R. (2003). Decentralizing Governance: Participation and Partnership in Service Delivery to the Poor. In D. A. Rondinelli \& G. S. Cheema (Eds.), Reinventing Government for the Twenty-First Century (pp. 195-218). Bloomfield: Kumarian Press 